\title{
MEMBANGUN MASYARAKAT SIPIL KRITIS : UPAYA PERLINDUNGAN HUKUM TERHADAP HAK ASASI MANUSIA (HAM)
}

Oleh :

\author{
Dr. Dian Ferricha, SH, MH \\ Dosen Universitas Islam Balitar
}

\begin{abstract}
ABSTRAK
Pandangan hidup bernegara telah dijelaskan dalam Undang-Undang Dasar 1945. Secara eksplisit dinyatakan bahwa Indonesia adalah negara hukum (rechstaat) bukan negara kekuasan (machstaat). Artinya tata cara bagaimana bertingkah laku antara subyek hukum satu dengan yang lainnya telah dinyatakan oleh para pendiri Negara Kesatuan Republik Indonesia (NKRI) pada waktu itu sekaligus meletakkan rambu-rambu kontrol atau pengendali terhadap siapa saja yang diberi kepercayaan untuk menyelenggarakan pemerintahan. Namun kenyataan marak sekali pelanggaran hak asasi manusia (HAM) dalam penerapan hukum yang bertujuan memberikan keadilan dan perlindungan kepada warganya. Masyarakat belum dianggap sebagai partner penentu kebijakan yang dapat memberikan solusi konkret terhadap permasalahan HAM. Anehnya masyarakat merupakan obyek yang terus dilemahkan oleh pemerintah. Hal ini berdampak pada kurangnya kepercayaan masyarakat terhadap segala kebijakan pemerintah mengenai HAM dan menumbuhkan krisis kepercayaan masyarakat terhadap pemerintahan yang ada. Untuk itu dibutuhkan solusi dalam perlindungan hukum terhadap HAM yaitu Pemerintah diharapkan lebih memberdayakan masyarakat untuk ikut andil dalam menentukan segala kebijakan (policy) terutama pada penyelesaian HAM dan penegakan supremasi hukum sehingga akan mempermudah terciptanya masyarakat sipil yang kritis terhadap perlindungan hukum di bidang HAM.
\end{abstract}

Kata kunci : masyarakat kritis, perlindungan hukum, hak asasi manusia.

\section{PENDAHULUAN}

Pada dasarnya prinsip dan semangat Pancasila adalah menjunjung tinggi martabat dan hak-hak asasi manusia sebagaimana tertuang dalam batang tubuh UUD 1945. Salah satu klausul dimaksud sebagai berikut :

“ Setiap orang berhak atas perlindungan diri pribadi, keluarga, kehormatan, martabat, dan harta benda yang dibawa kekuasaan, serta berhak atas rasa aman dan

${ }^{\infty}$ Penulis adalah Dekan Fakultas Hukum Universitas Islam Balitar. 
perlindungan dari ancaman ketakutan untuk berbuat atau tidak berbuat sesuatu yang merupakan hak asasi "“.

Secara eksplisit, regulasi normatif di atas memberikan pemahaman dan justifikasi pengakuan terhadap hak asasi manusia (HAM) sebagai hak dasar kodrati yang melekat pada diri manusia, bersifat universal dan langgeng ${ }^{2}$. Untuk itu harus dilindungi, dihormati, dipertahankan, dan tidak boleh diabaikan, dikurangi atau dirampas oleh siapa pun.

Bangsa Indonesia sebagai bagian dari subyek hukum Internasional dan secara de jure sebagai negara hukum (rechstaat). Tentu saja dalam memandang keberadaan HAM tidak terlepas dari semangat kesepakatan Internasional tentang HAM. Guna memajukan dan mendorong pencapaian kerjasama internasional mengenai penghormatan HAM, maka negara Indonesia diharuskan berpegang teguh pada hukum HAM internasional (international human rights law). Dengan kata lain para pemegang kekuasaan negara bukan saja harus melaksanakan kewajibannya, tetapi juga bertanggung jawab atas pelanggaran atau pengingkaran $\mathrm{HAM}^{3}$. Sehingga Indonesia sebagai anggota Perserikatan Bangsa-Bangsa berkewajiban memajukan penghormatan HAM dan memberikan perlindungan hukum bagi segenap masyarakat Indonesia.

Ironinya, hingga kini peristiwa pelanggaran HAM masih saja terjadi di sekitar kita. Rentetan fakta kekerasan yang dilakukan aparat kepolisian, mulai dari kasus yang sifatnya struktural, sebagaimana terjadi di Bulukumba dan Manggarai ${ }^{4}$, kasus yang bernuansa politik seperti terjadi di Aceh dan UMI Makasar ${ }^{5}$ sampai pada kasus Marsinah dan Udin $^{6}$ yang menghebohkan. Lebih dari itu masih membekas dalam ingatan ketika beberapa mahasiswa terpaksa menjadi korban penembakan sebagai tumbal reformasi dalam kasus yang dikenal dengan Tragedi Jembatan Semanggi.

Fenomena pelanggaran HAM terus tumbuh dan berkembang sementara penyelesaian hukum atas kasus-kasus dimaksud tidak pernah tuntas dan berakhir.

\footnotetext{
${ }^{1}$ Pasal 28 G ayat 1 UUD 1945 Amandemen ke empat. Yang dipertegas lagi dengan Pasal 28 A, Pasal 28 B, Pasal 28 D, Pasal 28 E, dan Pasal 28 I Undang-Undang Dasar 1945

2 Kesepakatan Internasional mengenai Declaration of Human Right. Lengkapnya di http://www.indomedia.com

${ }^{3}$ Substansi perjanjian Internasional pada pertemuan Perserikatan Bangsa-Bangsa, dalam sidangnya 16 Desember 1966

${ }^{4}$ terjadi pada tahun 2000

${ }^{5}$ http://www.suarapembaruan.com

${ }^{6}$ kasus aktivis buruh Marsinah terjadi pada tahun 2000. sedangkan Bernas Fuad Muhammad Syafruddin alias Udin, kasus pembunuhan pada Maret 2003. http://.www.indomesia.com
} 
Kasus Tanjung Priok salah satu contoh bahkan kasus pembunuhan terhadap pejuang HAM Munir dalam perjalanan studinya menuju Amsterdam, Belanda ${ }^{7}$.

Banyaknya kasus pelanggaran hak sipil terhadap para aktivis HAM mulai dari teror, penyiksaan (torture), penculikan, penahanan hingga pembunuhan di luar proses hukum (extrajudical killing) mengindikasikan bahwa perlindungan hukum terhadap masyarakat sipil yang kritis belum menjadi agenda serius pengambil keputusan. Seharusnya perlindungan hukum dan penghormatan terhadap HAM mutlak dilaksanakan.

\section{PERMASALAHAN}

Persoalan mendasar justru terletak pada upaya :

1. Bagaimanakah membangun masyarakat sipil yang peka dan tanggap terhadap pelanggaran HAM di tengah ketidakpastian hukum di negeri ini?

2. Apa saja kendala-kendala dalam upaya membangun masyarakat sipil yang kritis terhadap pelanggaran HAM dan bagaimana mengatasinya?

Berdasarkan hal tersebut, penulis tertarik mengkaji, menganalisis serta memberi pemecahan solusi (problem solving) mengenai permasalahan tersebut. Dengan harapan agar masyarakat sipil mempunyai kepekaan dan berpikir kritis, sehingga mampu memberi kontribusi kontrol terhadap pemerintah dan mampu mencari solusi cerdas sebagai aksi menghentikan pelanggaran HAM yang terjadi di seputar kita. Relevansi dari agenda dan harapan demikian didasari oleh paradigma otonomi daerah yang melahirkan kantong-kantong kekuasaan dengan segala keterbatasan sehingga pelanggaran HAM sangat potensial terjadi. Penulis mengharap implikasi dari hasil kajian ini kelak membuka mata hati masyarakat sehingga mampu mempengaruhi proses pengambilan keputusan di daerahnya bahwa apresiasi terhadap HAM menjadi agenda utama sebagai salah satu tolok ukur keberhasilan membangun aspek kodrati sumberdaya manusia.

\footnotetext{
${ }^{7}$ Menurut Elsam (Lembaga Studi dan Advokasi Masyarakat), kematian Munir merupakan akumulasi dari sekian banyak kasus yang menimpa para aktivis HAM. Penangkapan, penculikan, teror, penahanan, ancaman, intimidasi hingga pembunuhan, memang kerapkali dihadapi dan dialami oleh aktivis HAM. pada situs http://.www.jaknes.com
} 


\section{HASIL PEMBAHASAN}

\subsection{Membangun Masyarakat Kritis}

Sebagai salah satu upaya dalam mencapai tujuan dari penulisan penelitian ini di perlukan adanya suatu dasar hukum dan kerangka teoritis guna memberikan bukti konkret atas permasalahan yang dibahas.

Dasar hukum dimaksudkan untuk memberikan landasan yuridis atas permasalahan yang dibahas. Adapun dasar hukumnya yaitu :

A. Undang-Undang Dasar 1945

1. Pasal $28 \mathrm{~A}$

Setiap orang berhak untuk hidup serta berhak mempertahankan hidup dan kehidupannya;

2. Pasal $28 \mathrm{C}$ ayat 2

Setiap orang berhak untuk memajukan dirinya dalam memperjuangkan haknya secara kolektif untuk membangun masyarakat, bangsa, dan negaranya;

3. Pasal $28 \mathrm{D}$ ayat 1

Setiap orang berhak atas pengakuan, jaminan, perlindungan, dan kepastian hukum yang adil serta perlakuan yang sama di hadapan hukum;

4. Pasal $28 \mathrm{E}$ ayat 2 dan 3

(2). Setiap orang berhak atas kebebasan meyakini kepercayaan, menyatakan pikiran dan sikap, sesuai dengan hati nuraninya;

(3). Setiap orang berhak atas kebebasan berserikat, berkumpul, dan mengeluarkan pendapat.

5. Pasal 28 G ayat 1 UUD 1945 Undang-Undang Dasar 1945

Setiap orang berhak atas perlindungan diri pribadi, keluarga, kehormatan, martabat, dan harta benda yang dibawa kekuasaan, serta berhak atas rasa aman dan perlindungan dari ancaman ketakutan untuk berbuat atau tidak berbuat sesuatu yang merupakan hak asasi;

6. Pasal 28 I UUD 1945

1. Hak untuk hidup, hak untuk tidak disiksa, hak kemerdekaan pikiran dan hati nurani, hak beragama, hak untuk tidak diperbudak, hak untuk diakui sebagai pribadi di hadapan hukum, dan hak untuk tidak dituntut atas dasar hukum yang 
berlaku surut, adalah hak asasi manusia yang tidak dapat dikurangi dalam keadaan apa pun;

2. Setiap orang berhak bebas dari perlakuan yang bersifat diskriminatif atas dasar apa pun dan berhak mendapatkan perlindungan terhadap perlakuan yang bersifat diskriminatif itu;

3. Identitas budaya dan hak masyarakat dihormati selaras dengan perkembangan zaman dan peradaban;

4. Perlindungan, pemajuan, penegakan, dan pemenuhan hak asasi manusia adalah tanggun jawab negara, terutama pemerintah;

5. Untuk menegakkan dan melindungi hak asasi manusia sesuai dengan prinsip negara hukum yang demokaratis, maka pelaksanaan hak asasi manusia dijamin, diatur, dan dituangkan dalam peraturan perundang-undangan.

\section{Gagasan tentang Hak Asasi Manusia secara Universal dan Regional.}

Gagasan mengenai pemajuan, pemenuhan, perlindungan dan penegakan HAM yang fundamental pertama kali digulirkan oleh para pakar dunia barat sesuai alur berpikir mereka yang lebih menekankan kepada kepentingan individu daripada kepentingan kelompok yang diregulasikan pada bentuk perundang-undangan yaitu Undang-Undang Hak Virginia Tahun 1776 dalam sebuah Konstitusi merika Serikat Tahun 1791 dan Deklarasi Hak Asasi Manusia dan warga negara Perancis Tahun 1789.

Instrumen HAM yang bersifat universal ini mencerminkan pluralitas normatif di seluruh dunia. Sehingga lahirlah Deklarasi Universal Hak Asasi Manusia Tahun $1948{ }^{10}$. Negara-negara dunia yang tergabung juga dalam PBB tidak menolak eksistensi deklarasi tersebut. Dibuktikan pada konsolidasi pertemuan Internasional HAM di Teheran tahun 1968 dan di Wina tahun 1993.

Disamping tatanan universal, terdapat sejumlah konvensi yang bersifat regional mengenai HAM berupa konvensi Eropa bagi perlindungan HAM dan kebebasan yang fundamental tahun 1950, konvensi Amerika tentang HAM tahun 1969 serta hak rakyat bangsa Afrika tahun 1981. Konvensi Regional tentang HAM ini dimaksudkan untuk menetapkan HAM secara lebih khusus atau mempertajam standar HAM universal berkaitan dengan keadaan wilayah geografis tertentu. Sedangkan definisi dari HAM ialah seperangkat hak yang melekat pada hakikat dan keberadaan manusia yang wajib

${ }^{10}$ Prof. Dr. Makmuri Muchlas, Ph.D, Sp.Kj, Diseminasi Rencana Aksi Nasional (RAN) HAM Bidang Pendidikan. Jakarta : Biro Hukum dan Organisasi Sekretariat Jenderal Departemen Pendidikan Nasional. 2002 
dihormati, dijunjung dan dilindungi oleh negara, hukum, pemerintah, kelompok dan setiap orang tanpa terkecuali demi kehormatan dan perlindungan harkat dan martabat manusia ${ }^{11}$.

\section{Ciri Khas Hak Asasi Manusia}

Adapun ciri khas daripada HAM yaitu :

1. Inheren

Yaitu hak asasi manusia ada sejak lahir dan melekat pada setiap manusia.

2. Universal

Ialah HAM yang berlaku untuk untuk semua orang tanpa membedakan status, suku bangsa, agama, jender atau perbedaan lain.

3. Tidak dapat dicabut

HAM tidak dapat dicabut atau dialihkan

4. Tidak dapat dibagi

Maksudnya, setiap orang berhak untuk mendapatkan semua hak, baik sipil dan politik maupun hak ekonomi, sosial dan budaya. Sedangkan karya tulis ilmiah ini lebih menekankan pada cakupan hak sipilnya yaitu misalnya kebebasan berbicara dan kebebasan dari penyiksaan ${ }^{12}$.

5. Interdepedensi

Yaitu, pemenuhan dan perolehan suatu HAM yang dipengaruhi oleh pemenuhan dan perolehan hak asasi lainnya. Lebih jelasnya, hak sipil dan politik memungkinkan orang untuk memperoleh hak ekonomi, sosial dan budaya yang lebih baik.

\section{Konsep Pemberdayaan Masyarakat}

Menurut Franz Magnis Suseno bahwa upaya pemberdayaan masyarakat warga tidak bisa terlepas dari kualitas kebijakan-kebijakan politik yang dikeluarkan oleh pemerintah. Ketika kebijakan-kebijakan yang dibuat tidak kondusif bagi hidupnya kesukarelaan, keswasembadaan, keswadayaan, kemandirian yang tinggi berhadapan dengan negara, dan keterikatan dengan norma-norma moral secara leluasa sebagai

$11 \mathrm{ibid}$
$12 \mathrm{ibid}$ 
napas utama dari civil society dalam sistem politik, masyarakat warga tidak mungkin bisa berdaya ${ }^{13}$.

Sedangkan Ginanjar Kartasasmita ${ }^{14}$ mendiskripsikan :

"Dalam suatu kondisi ketimpangan, yakni dengan membangkitkan keberdayaan mereka. Sehingga mereka pun memiliki bagian dari power, yang memungkinkannya memperbaiki kehidupan atas kekuatannya sendiri. Inilah konsep empowerment atau pemberdayaan ".

Dikatakan pemberdayaan masyarakat dikarenakan merupakan sebuah konsep pembangunan ekonomi yang merangkum nilai-nilai sosial, bertujuan untuk melepaskan belenggu kemiskinan dan keterbelakangan, serta memperkuat posisi lapisan masyarakat dalam struktur kekuasaan. Dijelaskan, konsep ini tidak mempertentangkan pertumbuhan dengan pemerataan, tetapi bahwa pola pertumbuhan sama pentingnya dengan laju pertumbuhan itu sendiri. Ginandjar mengatakan, pertumbuhan yang tepat (the right kind of growth), yakni bukan yang vertikal menghasilkan tetesan ke bawah.

Konsep pemberdayaan masyarakat yang hadir dalam kerangka pemikiran masyarakat selaku subyek pembangunan bisa digunakan sebagai konsep alternatif. Hal ini ditegaskan oleh Ginandjar bahwa upaya dalam memberdayakan masyarakat tersebut mempunyai beberapa prasyarat, diantaranya : pertama, adanya iklim yang baik bagi perkembangan, dan kondusifnya iklim konstitusi di bidang HAM; kedua, terdapat usaha untuk memperkuat potensi masyarakat yang direlasikan pada peran serta masyarakat dalam pengawasan dan kontrol sosial pada pelanggaran HAM di Indonesia. Dan ketiga, ada upaya untuk melindungi dan mencegah persaingan yang tidak seimbang dalam masyarakat. Hal ini, menurut penulis lebih mendasar pada adanya jiwa nasionalisme yang tinggi terhadap NKRI, sehingga nantinya masyarakat akan lebih peka, kritis dan tanggap terhadap permasalahan HAM. Harapannya, konstruksi tujuan akhir konsep ini adalah memandirikan masyarakat sipil, dan membangun kemampuan untuk memajukan masyarakat sipil kearah kehidupan yang lebih baik secara berkesinambungan. Hal senada juga diperkuat dari doktrin Ginanjar

\footnotetext{
${ }^{13}$ Franz Magnis Suseno, Membongkar Mitos Masyarakat Madani dalam buku yang ditulis oleh Prof Dr M Dawam Rahardjo, Pustaka Pelajar Yogyakarta, Edisi: Juni 2000

14 Ginandjar, Masyarakat harus diberi Kepercayaan, Rabu, 20 Nopember 1996, Republika
} 
yang berpolitik hukum untuk melepaskan diri dari perangkap zero sum game (kesiaansiaan) dan trade off (ketimpangan).

Sejarah perkembangan hak asasi dimulai dari segi hukum berupa persamaan di hadapan hukum. Walaupun menunjukkan perkembangan masih disambut dengan berbagai keluhan dan ketidakpuasan. Hal ini terjadi karena persamaan hukum hanyalah merupakan dasar yang sepatutnya dipunyai dan dinikmati oleh setiap anggota masyarakat. Begitu juga dengan negara hukum yang selalu berorientasi pada dimensi negara demokratis konstitusional terutama pada keberadaan hukum yang supreme. Dimana regulasinya harus mengacu pada substansi hukum. Idiilnya, hukum harus berpijak pada Hak Asasi Manusia (HAM) dimana hukum harus melindungi hak-hak rakyat.

Dalam perspektif the law is as tool of social engeneering sebagaimana diungkapkan Roescoe Pound dalam teorinya, tidak lebih sebagai preseden hukum yang berorientasi pada pemberdayaan fungsi hukum dalam upaya membangun masyarakat sipil yang kritis terhadap pelanggaran HAM sebagai alat rekayasa sosial. Menurut hemat penulis, akan sangat mendukung tercapainya tujuan dimaksud. Chambliss dan Seidmen menambahkan, proses social engeneering dapat berhasil jika perubahan itu dibangun secara melembaga sebagai acuan pola tingkah laku di masyarakat. Sehingga, dengan mengacu pada fungsi hukum yaitu sebagai sarana kontrol serta sebagai sarana untuk melakukan social engeneriing guna mencapai proses pelembagaan yang diinginkan oleh masyarakat dan sesuai dengan berlakunya norma di masyarakat.

Untuk itu, penulis menganalisa bahwa selama ini isu-isu strategis tentang lemahnya perlindungan hukum terhadap HAM pada terciptanya masyarakat kritis, yakni : Pertama pemerintah masih berkutat bahkan mempertahankan paradigma lama pada penegakan HAM, Kedua amanat konstitusi yang menyangkut pembangunan HAM masih sebatas cita-cita, Ketiga terkikisnya moral dan rasa kekeluargaan antar sesama, Keempat pemerintah lebih mengedepankan cara kekerasan daripada proses dialogis persuasif untuk menangani persoalan HAM, Kelima rendahnya kemampuan profesi aparat hukum dalam menguak tabir kejahatan politik, Keenam Substansi hukum yang kurang menjamin dan mengakomodasikan perlindungan HAM, Ketujuh Perjuangan HAM identik dengan kekerasan, dan rendahnya sosialisasi tentang pemahaman akan keberadaan dan pentingnya HAM. 


\subsection{Kendala dan Solusi}

Dengan demikian, penulis menilai eksistensi HAM ditandai dengan serangkaian perjuangan yang cenderung mengarah ke dalam bentuk perubahan. Secara de facto, masalah HAM akan terus tumbuh dan berkembang dengan dinamikanya mengingat kekuasaan sangat potensial melebihi otoritasnya. Keterkaitan ini, diperkuat oleh Hegel ${ }^{22}$ dalam tulisannya "Reason of History" yang mengatakan :

“ Segala sesuatu tentang manusia merupakan bagian negara, karena didalamnya ia menemukan esensinya. Semua nilai yang dimiliki oleh manusia, semua realitas spiritual ia mendapatkannya dari jiwa yang ada pada rakyat ".

Berdasarkan hal tersebut, hemat penulis bahwa sebuah kontribusi itu sangatlah penting guna menumbuhkan kekritisan masyarakat. Namun, pada pelaksanaannya akan menemui kendala-kendala baik secara formil maupun materiil dalam perkembangan menuju tindakan, polarisasi kendala dan hambatan nantinya akan muncul. Dikarenakan pewacanaan HAM di masyarakat mengandung kritikan, redifinisi dan sintesa terhadap keberadaan HAM seperti yang termaktub pada pendapat Yap Thiam Hien $^{23}$

"Tadinya hak asasi lebih sering dihubungkan dengan suatu pelanggaran. Karena itu masalah hak asasi adalah bidang di mana para ahli hukum bergerak. Sehingga, hak asasi manusia lebih diasosiasikan dengan sesuatu yang hilang, yang tidak normal, baru suatu gerak diperlukan. Yang hilang itu sebagai suatu wacana tidak semata-mata mempersoalkan apa yang hilang tetapi apa yang harus dibangun, dibentuk dan ditumbuhkan. Kalau tadinya semata-mata suatu via negativa, menghindari pelanggaran, kini menjadi via positiva, membangun human dignity dan membuatnya menjadi dasar social and political decisions ".

Untuk itu, penulis memaparkan beberapa esensi kendala serta solusi dalam proses penegakan HAM dan supremasi hukum guna membangun masyarakat sipil yang kritis terhadap pelanggaran HAM, antara lain :

1). Pemahaman Konsep HAM

Kendalanya, masyarakat kurang peka terhadap permasalahan HAM karena pemahaman konsep HAM masih parsial. Keadaan demikian dilatarbelakangi oleh keterbatasan wacana pemahaman yang berkembang di masyarakat bahwa eksistensi HAM hanya milik kaum elit penguasa. Sehingga menumbuhkan sikap apatis

\footnotetext{
${ }^{22}$ Hegel pada tulisannya Reason of History dicuplik dari buku Bambang Sunggono, SH, MS, Aries Harianto, SH, Bantuan Hukum Dan Hak Asasi Manusia, Penerbit Mandur Maju, 2001, Bandung

${ }^{23}$ Yap Thiam Hien, dalam bukunya Bambang Sunggono, S.H, M.S, Aries Harianto, S.H, Bantuan Hukum Dan Hak Asasi Manusia, Penerbit Mandur Maju, 2001, Bandung
} 
masyarakat pada pentingnya penegakan HAM dan supremasi hukum. Penulis menilai penyelesaiannya dengan meningkatkan media sosialisasi, baik media cetak maupun elektronik. Serta menumbuhkan kontrol sosial masyarakat dalam bentuk dialog dan hearing. Dengan kata lain mutlak dibuka ruang publik bagi masyarakat untuk memahami HAM tidak sebatas dalam tataran kognitif.

2). Militansi dan Semangat Aktivis HAM.

Adanya ketidakpercayaan pemerintah pada kinerja aktivis HAM, dimana aktivis HAM masih dinilai sebagai pihak yang berseberangan secara diametral dengan pemerintah dalam menyelesaikan permasalahan HAM. Mengakibatkan adanya campur tangan pihak luar (internasional) dalam menangani permasalahan HAM di Indonesia. Hemat penulis, kendala ini dapat diatasi dengan memperluas ruang gerak dan kewenangan LSM dan aktivis HAM dalam memperjuangkan penegakan HAM serta menjalin kerjasama dengan pemerintah dalam menindak pelaku pelanggaran HAM di Indonesia.

\section{3). Profesi Aparat Hukum}

Hambatan dalam membentuk penegakan HAM dan supremasi hukum guna membangun masyarakat sipil yang kritis terhadap pelanggaran HAM pada dimensi profesi aparat hukum ialah tidak profesionalnya aparat hukum dalam memberikan pemahaman dan sosialisasi kepada masyarakat atas eksistensi HAM dalam ranah penegakan supremasi hukum. Hal ini bisa diatasi tidak saja dengan mereposisi aparat hukum tetapi juga mendesak diberikan nilai tambah profesi dalam menindak pelanggaran HAM serta memberi award kepada aparat hukum yang berprestasi dalam menegakkan HAM dan supremasi hukum di Indonesia.

4). Gerakan Mahasiswa

Kendalanya, stagnasi pemikiran kritis mahasiswa sebagai agent of change dan agent of control terhadap fenomena penegakan HAM, sehingga gerakan mahasiswa tidak massif. Analisis penulis guna mengatasi permasalahan ini ialah dengan menstimulasi basis-basis mahasiswa di Perguruan Tinggi melalui menambah sarana dan prasarana dalam menunjang gerakan mahasiswa kritis di bidang HAM, semisal dengan memperkaya stok buku-buku HAM di perpustakaan, mengadakan debat dan forum ilmiah mengenai permasalahan HAM yang ada. Tidak kalah pentingnya adalah dengan mengakomodasikan persoalan-persoalan HAM potensial kedalam kurikulum yang diterapkan. Lebih-lebih dewasa ini sistem kurikulum berbasis kompetensi (KBK) mulai diimplementasikan. 


\section{5). Political will Pemerintah}

Minimnya sarana dan prasarana dalam menegakkan supremasi hukum guna menyelesaikan masalah HAM. Hal ini tidak akan terjadi jika pemerintah memberikan fasilitas berupa finansial dan award kepada pejuang HAM dan masyarakat yang peduli terhadap penegakan HAM di Indonesia seperti dengan membuat dan mengeluarkan kebijakan berupa pencanangan penghargaan tahunan dalam bentuk Local Human Rights Award di lingkup Pemkab setempat serta Munir Award dalam skala nasional (Pemerintah Pusat). Sehingga, penghargaan seperti ini pada gilirannya akan meningkatkan daya apresiasi publik terhadap konsistensi penegakan hukum dan HAM di wilayah masing-masing.

6. Penegakan Hukum

Miskinnya bentuk nyata perlindungan hukum terhadap aktivis dan pejuang HAM. Secara ideal, penulis menilai perlunya diadakan harmonisasi perundangUndangan nasional disamping substansi normatif dimaksud secara esensiil merepresentasikan persoalan HAM baik kini mupun mendatang. Cita-cita demikian patutlah ditindaklanjuti secara serius dalam aspek praktis penegakan hukumnya. Satu hal lagi bahwa di era dewasa ini pemerintah patut mengulang kembali politik strategi dua muka sebagai tradisi yang diterapkan orde baru dalam menjalankan politik hukumnya.

\section{KESIMPULAN}

Hukum bersifat social engeneering yaitu proses mencapai sasaran yang diinginkan. Adanya dimensi isu strategis dalam perlindungan hukum terhadap HAM berorientasi pada pemberdayaan fungsi hukum dalam upaya membangun masyarakat sipil yang kritis terhadap pelanggaran HAM sebagai alat rekayasa sosial. Esensi kendala serta solusi dalam proses penegakan HAM dan supremasi hukum guna membangun masyarakat sipil yang kritis terhadap pelanggaran HAM, antara lain : Pertama, pemahaman konsep HAM yang masih parsial. penyelesaiannya dengan meningkatkan media sosialisasi, dialog dan hearing. Kedua, militansi dan semangat aktivis HAM yaitu ketidakpercayaan pemerintah oleh kinerja aktivis HAM yang dinilai berseberangan secara diametral. Dapat diatasi dengan memperluas ruang gerak dan kewenangan LSM dan aktivis HAM. Ketiga, profesi aparat hukum yang kurang profesional. Hal ini bisa diatasi tidak saja dengan mereposisi aparat hukum tetapi juga mendesak diberikan nilai tambah profesi dalam menindak pelanggaran HAM serta 
memberi award kepada aparat hukum yang berprestasi. Keempat, gerakan mahasiswa pada stagnasi pemikiran kritis. Dapat diatasi dengan menstimulasi basis-basis mahasiswa di Perguruan Tinggi. Tidak kalah pentingnya dengan mengakomodasikan persoalan-persoalan HAM potensial kedalam kurikulum yang diterapkan. Kelima, political will pemerintah dengan minimnya sarana dan prasarana dalam menegakkan supremasi hukum. Hal ini tidak akan terjadi jika pemerintah memberikan fasilitas berupa finansial dan award kepada pejuang HAM dan masyarakat yang peduli terhadap penegakan HAM. Dan terakhir pada penegakan hukum yakni miskinnya bentuk nyata perlindungan hukum terhadap aktivis HAM. Perlu diadakan harmonisasi perundang-Undangan nasional disamping substansi normatif pada persoalan HAM. Dengan inventarisasi tersebut, diharapkan kepada Pemerintah untuk lebih memberdayakan masyarakat untuk ikut andil dalam menentukan segala kebijakan (policy) terutama pada perlindungan hukum dalam menyelesaikan masalah HAM.

\section{DAFTAR PUSTAKA}

A. Buku

Bambang Sunggono, S.H, M.S, Aries Harianto, S.H, Bantuan Hukum Dan Hak Asasi Manusia, Penerbit Mandur Maju, Bandung, 2001

Komisi Nasional Hak Asasi Manusia, Hak Asasi Manusia dalam perspektif budaya indonesia, Penerbit PT Gramedia Pustaka Utama, Jakarta, 1997

B. Peraturan Perundang-Undangan

Undang-Undang Nomor 5 Tahun 1998 tentang Pengesahan Konvensi menentang penyiksaan dan perlakuan atau penghukuman lain yang kejam, tidak manusiawi atau merendahkan martabat manusia

Undang-Undang Nomor 9 Tahun 1998 tentang Kemerdekaan Menyampaikan Pendapat di Muka Umum

Undang-Undang Nomor 39 Tahun 1999 tentang Hak Asasi Manusia

Undang-Undang Nomor 26 Tahun 2000 tentang Pengadilan Hak Asasi Manusia

C. Sumber lain

http://www.indomedia.com

http://.www.jaknes.com 